\title{
The Need for Incorporating Sustainability Thinking into Higher National Diploma Electrical/Electronic Engineering Curriculum in Nigeria
}

\author{
Nasiru Mukhtar ${ }^{1}$ \& Muhammad Sukri Bn Saud ${ }^{2}$ \\ ${ }^{1}$ Department of Science and Technical Education, Bayero University, Kano, Nigeria \\ ${ }^{2}$ Department of Technical and Engineering Education, Universiti Teknologi Malaysia, Johor, Malaysia \\ Correspondence: Nasiru Mukhtar, Department of Science and Technical Education, Bayero University, Kano, \\ Nigeria. E-mail: nmukhtarbichi@gmail.com
}

Received: August 26, $2018 \quad$ Accepted: July 28, $2019 \quad$ Online Published: July 29, 2019

doi:10.5539/ass.v15n8p113 URL: https://doi.org/10.5539/ass.v15n8p113

\begin{abstract}
The fundamental substance employed for energy, construction, smelting and shipbuilding before eighteenth century was wood. However, with the advent of industrial revolution, changes in agriculture, manufacturing, mining, transportation, and technology had an overwhelming consequence on the socio-economic life of the society. This causes natural resources to decline and demand for them to incredibly increase, which led the humanity to fell into intertwined crises of environmental, economic and social systems. To change the situation, paramount changes of thinking and mindset are required and education is the key. This study therefore, explored the perceptions of electrical/electronic lecturers in the polytechnics on the need to incorporate sustainability thinking into Higher National Diploma electrical/electronic engineering curriculum in Nigeria. Two research questions guided the study through qualitative research design. Sixty-five (65) electrical/electronic lecturers in the polytechnics within the states under the study made up the target population, and only senior lecturers were selected to participate in the study. This is because of their experience in teaching electrical/electronic courses in the institutions. The authors conducted qualitative semi-structured interviews to generate data used in answering the research questions. The authors transcribed and thematically analyzed the data. Findings revealed a common view in which the participants indicated an urgent need for incorporation of sustainability thinking in to the said curriculum. Findings also showed the possible benefits of incorporating sustainability thinking to include environmental protection, economic prosperity, social wellbeing and technical sustainability. The authors recommended a model for incorporating sustainability thinking into HND electrical/electronic engineering curriculum.
\end{abstract}

Keywords: sustainable thinking; technical and vocational education; higher education institutions

\section{Introduction}

\subsection{Background of the Study}

Prior to the advent of industrialization in Europe in the mid-eighteenth century, wood was the basic substance used for fuel, building, and even ship construction (Blewitt, 2014). Global economic activities depended on an apt and what some agreed to be an endless source of timber. Nevertheless, time proved them incorrect. While timber is a certified renewable reserve, its harvesting by European countries was not commensurate with what they plant and raised to ripeness. Earlier than the eighteenth century, 'sustainability' was a strange word in the world and lacked notion on what it would connote for the proceeding centenaries. During those periods, natives typically cultivated and made their own food, and fabricated their own garments; electricity in homes and workplaces did not exist; nothing warranted extended transportation. Gu, Gomez and Brizuela (2011) asserted that life occurred indigenously, and that concepts such as 'globalization', 'fossil fuels', 'technology', and 'innovation' had neither sense nor significance.

However, with the advent of transformation in industry, the world evolved novel standards of life and dumped the ancient ones. The revolutionary activities in farming, manufacturing, mining, transport, and machinery impacted positively on the socio-economic facets of life in the society. Importantly, is the population's increase and earnings which had an unarguably never been like before. This increase in the world's population and 
earnings, coupled with the ill-defined distribution of the world resource, caused a new world circumstance; and most important ecosystems which are essential for sustaining the world's life forms, had been in considerable deterioration (UNEP, 2005). Owing to population increase and our novel life style obsessed by growing earnings, natural resources kept waning and their need is extremely increasing. The earth's ecosystem is stressed to sustain its rate of restoration. The Living Planet Report asserted that our universal footprint surpass the world's ability to regenerate by about 30 percent. If the world's need for natural resources persists to grow at the equal pace, by the decade of 2030, the world would require the equivalent to two planets to preserve our way of life (Leape, 2008). Unintentional repercussions due to new human behavioral paradigms about standard of living have triggered the challenge for society to maintain itself throughout generations, the so called 'sustainability challenge'.

The sustainability challenges surfaced because of normal systemic malfunction induced by an imbalance between limited cognitive, emotional, and organizational capacities of individuals and institutions on the one hand, and overly complex and high-risk technologies and production systems on the other hand. Sustainability challenge aftermaths include: water shortages, ecosystem loss, ocean acidification and sea level rise, disruption of food production and the food chain, more extreme weather events, disruptions of ecosystems and the spread of disease e.g. West Nile, Malaria, Dengue Fever, submersion of land masses etc (Rowe, undated). Three characteristics are identified to be common to these problems: they occur to some degree in all societies; they contain technical, social, economic, and political elements; and, most important of all, they interact. To reduce human sufferings, environmental degradation and social ills while building stronger economies, we need a rapid shift towards sustainability thinking and Technical Vocational Education is the key to action.

The fundamental foundation for any modern society existing today is education (e.g., Phiri, 2010). It has the sole responsibility of manpower or human development, seen as a process through which nations achieve to a large extent, self-sufficiency in the production of food, production of consumer and capital goods and services, management patterns and viable economic, social and political structures (Olaniyan \& Okemakinde, 2008; Ployhart \& Moliterno, 2011).

In Nigeria, development of human capital is expected to ensure among other things, adequate understanding of the environment, its preservation and eventually minimize environmental degradation, desertification, deforestation, soil erosion etc (UNESCO, 2005). In this regard, education provides the possibility of sustainable development via training the workforce to understand their environment, their role in it and the acquisition of proper knowledge and skills for the future challenges. Technical and Vocational Education (TVE) in Nigeria is responsible with discharging these tasks. Education and instruction for sustainability is a practice of learning how to make decisions that reflect on the lasting future of the economy, environment and society in the place of work and the broader community. Developing and fostering the competencies, obligations and steadfastness required for such sustainable-oriented education is a key task of TVE.

This is because sustainability is a foremost and growing concern for higher education and most institutions and organizations are being encouraged, in various approaches, to entrench programmes based on the philosophies and practices of sustainability within their undertakings. (Ukpai, 2012). Wiek, Withycombe, Redman and Mills (2011) stated that sustainability education programmes are not only to teach students for 'green jobs' save for prepare systematic problem solvers, change agents and transition managers. It is highly desirable that a lot of graduates should be 'sustainability literate' when they leave TVE institutes, having had the chance whilst at the school to discover sustainability problems within their own lives, their chosen branch of learning and their future careers.

However, TVE in many developing countries including Nigeria have remained locked in to the function of training and preparing semi-skilled workforce to the job market and therefore are rendered incapable to act in response to the needs of sustainability and sustainable society (Majumdar, 2009; Phiri, 2010; ADEA, 2012). Aderonmu (2012) stated that while TVE curriculum has continued to flourish well as regards to sustainability inclusion in many societies, Nigeria is yet to establish an institutional ideology capable of engendering sustainability education in her curriculum. Enabling citizens to escape from poverty and to develop sustainable livelihoods is both a key role for TVE and a pre-requisite for sustainable development, which brings together three pillars of development: social, environment and economy (UNESCO, 2008). Nevertheless, the current curriculum operated for TVE practices in Nigeria is in no way contributing to sustainable life of the people; certainly, several would claim that the curriculum have vigorously play a part to unsustainable living in the developing countries (Aderonmu, 2012). This is perhaps as a result of lack of framework for incorporating sustainability education in to the curriculum.

Therefore, developing and implementing changes in the curriculum to educate students in sustainability is 
essential to produce graduates with higher-level cognitive and critical as well as problem solving skills. Polytechnics in Nigeria need to put in place strategies for curricula adjustment and teaching-learning approach to achieve sustainable development goals. These changes in the curriculum are essential because clear evidences are available which showed that Nigerian society is promoting planet's catastrophe such as: increasing environmental strain, great wealth imbalance, an ecological impact of a human activity surpassing the earth's carrying capacity, increase of people who cannot provide for their basic needs, decreased biodiversity, and increased CO2 emission, pollution, depletion of natural resources (Dan'Azumi \& Bichi, 2010; Akinbile \& Yussof, 2011; Akinsanya \& Omotayo, 2013).

\subsection{Problem Statement}

Technical and Vocational Education programmes in Nigeria are faced by a hydra-headed obstacles and difficulties. As a result, TVE institutions are rendered to mere suppliers of semi-skilled or not-at-all-skilled labour to the job market; inability to train students with requisite knowledge, skills and attitudes in sustainability education; lack of institutionalized principles that can stimulate sustainable practices; and failure to make the graduates to build sustainable livelihoods (Bubou, Offor, \& Gumus, 2015; Mukhtar, 2014; UNESCO, 2016). These problems emanated due to the absence of a framework for incorporating sustainability thinking in the curricula. To this effect, researchers in TVE programmes have a very important role in addressing these challenges. To put an end to these challenges, there is need to entrench sustainability thinking into the TVE curricula. In view of the foregoing, this study employed qualitative research design to seek the perceptions of the electrical/electronic lecturers in the polytechnics on the need for incorporating sustainability thinking into Higher National Diploma electrical/electronic curriculum in Nigeria.

\subsection{Literature Review}

\subsubsection{The Concept of Sustainability}

Sustainability is a complex issue, encompassing economic, environmental, social and technical dimensions (WCED, 1987; Pappas, 2012; Sianipar et al., 2013). The complexity is obvious as sustainability preaches development to gratify human demands as well as enhance the worth of human life. On the same note, this development ought to be rooted upon the effective and conscientious utilization of the entire of humanity's limited resources - natural, human and economic. Sustainability requires us to acknowledge the interdependent relationship between people and the natural environment (UNESCO, 2008). This interdependence means we should not pursue the achievement of any single (social, economic, technical or environmental) objective to the detriment of others. This implies that it is a paradigm for thinking about the future, where the environment, the economy, the society and technical dimensions of sustainable development are intertwined and balanced in the pursuit of an improved quality of life (UNESCO, 2011).Sustainability is a way of thinking about how we organize our lives and work including our education system so that we don't destroy our most precious resource, the planet (Tilbury, 2011). The definition of sustainability is the study of how natural systems function, remain diverse and produce everything it needs for the ecology to remain in balance (Mason, 2017). Humankind possesses the capacity to ensure development is sustainable to attain to the needs of the present devoid of compromising the ability of upcoming generations to meet their own needs (WCED, 1987).

Sustainability takes into account how we might live in harmony with the natural world around us, protecting it from damage and destruction. It is an expansive branch of learning that affords students and graduates imminent associated with numerous facets of the human world from business to technology to environment and the social sciences. The underlying competencies in all of the dimensions or pillars of sustainability that students graduated from college or university with are graciously required, particularly in a contemporary world with strong desires to considerably cut down carbon emissions as well as find out and build up the technologies of the future (Mason, 2017). Sustainability competencies in environmental, economic, social and technical dimensions are precedence among several corporate careers at the level of graduate and beyond, as industries and businesses pursue to stick to new acts. As a result, graduates of sustainable education programmes will venture into various disciplines mainly manufacturing industries, civic planning, environmental consultancy (built and natural environment), agriculture, not for profit, corporate strategies, health assessment and planning, and even into law and decision making (Mason, 2017). Entry-level works are increasing and in the upcoming years, bachelor's graduates can anticipate increasing options and opportunities.

\subsubsection{The Need for Sustainability Thinking in TVE Programmes in Nigeria}

Sustainability thinking in TVE relates to a design of human and industrial systems to ensure that humankind's use of natural resources and cycles does not lead to diminished quality of life due to either losses in further economic opportunities or to adverse impacts on social conditions, human health and the environment (Mihelcic, 
et al., 2003 in Huntzinger et al., 2007). Current trends seem to indicate that the labor market is transforming and companies now sought for workforce with sustainability skills and understanding. This necessitates Colleges and Universities in developed and some developing countries to begin to incorporate sustainability education into their programmes. From undergraduate programmes to MBAs, Masters and even PhDs in sustainability and sustainable-business practices to non-formal programmes that affords graduates with the technical training required to operate renewable energy gadgets. TVE institutions in developing countries such as Nigeria should be able to support the sustainability base for this recent reality so that the students would be better equipped for entry into the labour market and generally, play a vital role to a more sustainable society. The jobs mostly, are in the fields of the economy served by Technical and Vocational Education and Training (TVET). Thus, TVET system requires deep immersion in the understanding and practices of sustainability. Majumdar (2009) opined that TVET can play an instrumental role in developing a new generation of individuals who will face the challenge of achieving sustainable socioeconomic development.

Sustainability experts (such as Rosen, 2012; Pappas, 2012; Nagel, Pappas, and Pierrakos, 2011) believed that the requisites of all the four dimensions of sustainability (environmental, economic, social and technical), ought to be stable in a TVE curricula, and unless these four elements are equally incorporated in to the learning objectives of the curriculum, TVE graduates in Nigeria will not truly be answering the call to participate in the design of sustainable societies. The figure below illustrates that the environmental, economic, social and technical dimensions of sustainability must come together synergistically. Hitherto there is important improvement required in TVE/engineering education curricula if the graduates are to be comprehensively equipped for the expected challenges ahead. Typically graduates lack understanding of environmental, social and economic impact, and are insensitive to cultural idiosyncrasies.

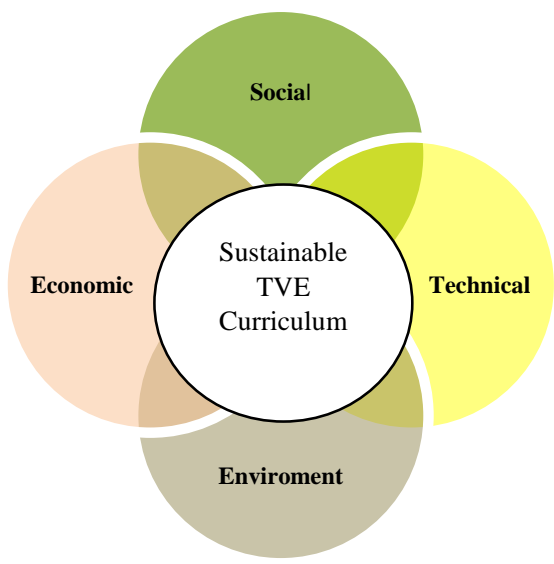

Figure 1. The balanced Environmental, Economic, Social and Technical Sustainability creates a Sustainable TVET Curriculum (Adapted from Nagel, Pappas, \& Pierrakos, 2012)

\subsection{Pillars of Sustainability}

\subsubsection{Environmental Sustainability}

Environmental sustainability is the ability to think of the environment as supporting a distinct degree of ecological worth and natural resource extraction rates without letting up. Environmental sustainability happens to be the pioneer pillar of sustainable development, and it necessitates a shift from "business as usual approach" to sustainable development approach of utilizing natural resources shrewdly, curtailing waste and curb destruction to atmosphere and control detrimental climate change. This connotes the dependable application of raw materials; energy, water, etc; and consciousness of the effects of manufacturing production processes and ecological appraisal system (Majumdar, 2009). Morelli (2013) a professional environmentalist, defined environmental sustainability as a condition of balance, resilience, and interconnectedness that allows human society to satisfy its needs while neither exceeding the capacity of its supporting ecosystems to continue to regenerate the services necessary to meet those needs nor by our actions diminishing biological diversity. The goal of environmental sustainability as viewed by professional environmental managers such as Butler (2009) is 'ecological balance', though may be separate, but related, from that of industrial environmental managers.

\subsubsection{Economic Sustainability}

Economic sustainability implies thinking towards a system of production that satisfies present consumption levels without compromising future needs (Basiago, 1998). The literature in economic sustainability revealed 
that classically, economists assumed that natural resources was indefinite, and this subjected the capacity of the market to apportion resources effectively to excessive emphasis. They supposed also that economic growth would lead to the technological might to restock natural resources ruined during the production process. Nowadays, an understanding has transpired that natural resources are not endless. The increasing scale of the economic system has burdened the natural resource base.

Economic Sustainability is the second pillar of sustainable development. It demands a separate and broader, array of economically related knowledge, skill and attitude vis-à-vis economic literacy, sustainable production and consumption and management of small, medium and large enterprise (Majumdar, 2009). Economic sustainability is the ability of an economy to support a defined level of economic production indefinitely. TVET graduates, more than ever before, are in dire need to acquire knowledge, skills and right attitudes and values in economic sustainability for high accomplishment in growing aggressive global economies coupled with the demand to tackle global issues caused by climate change and carbon emissions, environmental degradation and pollution, health, and poverty (Pavlova, 2014).

\subsubsection{Social Sustainability}

Social sustainability refers to the ability to think of a social system, such as a country, family, or organization, to perform at a distinct level of social welfare, safety, happiness, and harmony for an indefinite period. Problems like war, endemic poverty, widespread injustice, and low education rates are symptoms a system is socially unsustainable. Pappas (2012) refers to social sustainability as the ongoing human and institutional balance and prosperity that characterize a healthy social unit, and includes justice, equity, and fairness, the role of individuals, relationships among social groups, the family, collective behavior, social class, race and ethnicity, medicine, education, and the role of institutions in society. Cultural factors include the shared values, attitudes, beliefs, behaviors, and social practices that characterize human knowledge and action. To Choi and $\mathrm{Ng}$ (2011), the social dimension of sustainability is concerned with the well being of people and communities as a noneconomic form of wealth.

\subsubsection{Technical Sustainability}

Although technical sustainability is not among the original three pillars of sustainability, it has tortuous relationship to each (Rosen, 2012). For instance, technical/engineering processes utilize resources to propel majority of the global economic trades, in almost every fiscal sector, e.g., industry, transportation, residential, commercial, etc. Moreover, resources consumed in technical/engineering, whether fuels, minerals or water, are acquired from the environment, and wastes from engineering processes (production, transport, storage, utilization) are usually discharged to the environment. Lastly, the services and sacrament offered by technical/engineering permit for good living standards, and frequently corroborate social stability as well as cultural and social development. Given the close bind linking engineering and the basic constituents of sustainable development, it is obvious that the achievement of sustainability in technical/engineering is a vital facet of attaining sustainable development, in particular countries and globally (Rosen, 2012).

A positive footing in technical sustainability aids prevents misunderstanding as regards to engineering issues. Technical sustainability tackles a broad diversity of mechanical and technical factors that comprise the design and manufacture of products (Pappas, 2012). These include the scientific research and appropriate technology supporting product design, function and development; ease and efficiency of durable construction and use; maintenance and functioning capabilities that meets the objectives for which the product is designed; material selection and reduction, recovery, reuse or disposal of parts of unused materials (Skidar, 2009; Pappas, Pierrakos and Nagel, 2013). Technical sustainability supports manufacturing processes and industrial practices that are less persistent and destructive to environmental, social or economic contexts and produce preferably, neutral or positive impacts on these contexts.

\subsection{Objective of the Study}

The main objective of this study is to find out the need for incorporating sustainable thinking in to Higher National Diploma (HND) electrical/electronic engineering curriculum in Nigeria.

\subsection{Research Questions}

The following research questions are formulated to guide the study:

1) Is there any need for incorporating sustainability thinking in to Higher National Diploma electrical/electronic engineering curriculum in Nigeria? Why?

2) How incorporating sustainability thinking in to Higher National Diploma electrical/electronic engineering 
curriculum helps attain:

- Environmental protection?

- Economic prosperity?

- Social well being?

- Technical sustainability?

\section{Method}

\subsection{Method}

The design of the study was qualitative research design. The authors carried out the study in North-West geo-political zone of Nigeria consisting of seven (7) states. We used both Federal and State polytechnics offering electrical/electronic engineering programme in the study. The target population for the study was 65 electrical/electronic engineering lecturers in the ten (10) polytechnics in the study area. We used cluster sampling to select four states out of seven and these include Jigawa, Kaduna, Kano and Katsina states. Therefore, we used all the polytechnics that fall within these four states in the study. The researchers conducted ten (10) qualitative semi-structured interviews, and data was continually generated until it was saturated. The authors transcribed and thematically analyzed the data. Only senior lecturers and above are targeted because of their experience in teaching electrical/electronic courses in the institutions.

\subsection{Data Collection}

The authors used a semi-structured interview protocol to collect data from the electrical/electronic lecturers in the polytechnics. The lecturers were effectively briefed before and debriefed after the interviews. First of all, the researchers introduced themselves to the administration of the various polytechnics selected to participate in the study. After necessary approval to conduct the study from the administration, the researchers met with each head of electrical/electronic departments in the polytechnics, to explain the purpose and rationale of the study; and requested them to nominate senior lecturers from their department for the interview. We conducted qualitative semi-structured interviews ranging from 30-45 minutes. Secondary information was also used, which involved works carried out previously on ESD integration in sub-Sahara Africa. We also used authenticated information and the utilization of online information on the topic to bring together pertinent information about incorporating sustainability thinking in TVE programmes.

\subsection{Data Analysis}

As earlier stressed, the authors collected the data for answering the research questions using semi-structured interview with the participants. Firstly, the authors begin the data analysis by transcribing the audio-recorded version of the data immediately after the first interview. The researchers continued in the same manner of conducting the interview, transcribing the interview, before conducting the next interview until the researcher felt that the data reached a saturation point. Next, we subject the transcribed data to thorough reading and re-reading which was later presented to the interview participants for their corrections and confirmations. This was then exported in to Nvivo version 11 to help organize the data. Thematic data analysis was accomplished using Nvivo version 11 to condense the data to manageable and meaningful codes based on the research questions. In analyzing the interview data, the researchers opted for data benchmarking technique based on the reviewed documents related to the study. Dainty, Cheng and Moore (2010); and Calhoun et al. (2008) discussed and proposed data benchmarking techniques. This technique suggests the researcher to starts the analysis with a predetermined themes and coding based on the previously reviewed literature regarding the scope of the study.

Consequently, we modified the outcomes of the Nvivo version 11 in to a framework, and then analyzed with the help of the framework method analysis. Furthermore, broad analysis on the perceptions of the interview participants on the need to incorporate sustainability thinking into engineering curriculum is presented below. Accordingly, the researchers adapted a coding system for identifying the research participants to make it easier to recognize the data sources.

\section{Results}

Based on the qualitative data collected, transcribed, coded, analyzed and categorized, the following findings were made and presented in order of the research questions:

3.1 Findings of the Study on the Need to Incorporate Sustainable Thinking into the HND Electrical/Electronic Engineering Curriculum.

The electrical/electronic lecturers in the polytechnics interviewed emphasized the need and importance of 
incorporating sustainable thinking into HND electrical/electronic engineering curriculum in Nigeria. The respondents recognized the position of Nigeria in the global context, which emphasizes on sustainable oriented technology, economy and environment, as a principal driver that necessitates the development and incorporation of sustainability thinking into all higher education programmes. As such, for Nigeria to remain relevant leading Africa's best economy, she has to do the needful. This will make certain that through sustainability-based curriculum, the knowledge, skills and values of sustainability can be inculcated to present and future technology entrepreneurs and practioners.

The respondents also recognized that the learning environment would be conducive and safe, technical education would be affordable to the students, there would be state-of-the-art facilities, equipment and machines needed for technical education both in the laboratory and classroom to improve the students' and lecturers' skills; and the relationship between the staff and students would be sustainably good for human development if sustainability thinking is incorporated into HND electrical/electronic engineering curriculum.

The respondents foresee the merits of incorporating sustainable thinking coming from having a society that would be free from environmental, economic, social and technical consequences of the activities of manufacturing and service industries. They also commented that technical and engineering programmes in Nigeria in general, if enriched with sustainability thinking can have a capacity to play an instrumental role in developing a new generation of individuals who will face the challenges of achieving sustainable socio-economic development.

\subsection{Findings of the Study as to how incorporating sustainability thinking in to HND electrical/electronic engineering curriculum helps attains:}

\subsubsection{Environmental Protection}

Respondents interviewed commented on possible effects of incorporating sustainable thinking into the curriculum on environmental protection in Nigeria. The interviewees dwelt on waste recycling and renewable energy techniques as possible skills the students will benefit from after passing through a sustainability-based curriculum. The respondents see sustainability thinking as essential to fathom the means of developing strategies for protecting the environment from harmful events such as resource depletion, increased in greenhouse gases, spread of diseases, climate change, water scarcity and loss of natural habitats and biodiversity.

\subsubsection{Economic Prosperity}

Respondents discussed about producing strong future labour force which will enhance the country's Gross Domestic product (GDP). Addressing present widespread job losses, insecurity, and financial risk to governments and public programs were also highlighted as part of the benefits the country will stand to gain as a result of incorporating sustainability thinking in to education system. On a general note, the interviewees unanimously talked about positive thinking towards a system of production that satisfies present consumption levels without compromising future needs.

\subsubsection{Social Wellbeing}

Respondents linked sustainability thinking to providing solutions to problems like war, endemic poverty, widespread injustice, and low education rates if adequately incorporated in to TVE programmes. They also believed that sustainability thinking would aid in preparing the graduates to have an intelligent understanding about social justice and gender equality, democracy, human rights and ethics, work environment issues, such as occupational safety and individuals being to work with one another, accessibility issues and issues related to education. Another important point highlighted was job security which is vital in preventing a substantial amount fo social vices like insurgency, arm robbery, rampant kidnapping, thuggery, and prostitution which have become common phenomena in today's Nigerian society.

\subsubsection{Technical Sustainability}

The respondents mentioned that sustainability thinking will enable graduates of HND electrical/electronic engineering to have a complex understanding of a wide variety of mechanical and technical factors that constitute the design and manufacture of products, processes and systems. Along the same line, the respondents also viewed sustainability thinking as capable of promoting technical sustainability which in turn, promotes manufacturing processes and industrial practices that are less invasive or destructive to environmental, social or economic contexts and yield ideally, neutral or positive effects on these contexts.

\section{Discussion}

On issues related to the need for incorporating sustainability thinking in to the higher national diploma 
electrical/electronic engineering curriculum in Nigeria, the respondents emphasized its importance and urgency for its implementation. Reasons advanced by the respondents include: the leadership position the country is holding as the best economy in Africa; having a society that would be free from environmental, economic, social and technical consequences of the activities of manufacturing and service industries; the possibility of technical and engineering education to play an instrumental role in developing a new generation of individuals who will face the challenges of achieving sustainable socio-economic development. These findings are in line with the recommendations of The UN Decade of Education for Sustainable Development (DESD), which demands for a scrupulous incorporation of competencies in sustainability issues at all levels of education via a holistic, interand trans-disciplinary approach and with a clear focus on values (UNESCO, 2009). In support of this, Hidalgo and Arjona Fuentes, (2013) reported that in order for the numerous sustainability-related problems to be addressed there is an urgent need to reorient the school curricula, so that appropriate sustainability competencies (knowledge, skills and attitudes) are injected.

Furthermore, Gu, Gomes and Brizuela, (2011) asserted that the development of knowledge, skill and attitudes in its entirety is a significant facet in TVET due to its practical nature. We observed that to improve the pace of the nation's technological and sustainable development, higher education students should acquire relevant knowledge, skills and desirable work habits. Also for Nigeria to remain relevant leading Africa's best economy, she cannot afford to sit back as regards to sustainability matters in formal and informal organizations. Sustainability competencies in environmental, economic, social and technical dimensions are a priority in many corporate jobs at graduate level and over, as industries and businesses seek to adhere to new legislation. Therefore, Sustainability graduates will go into many fields most commonly manufacturing industries, civic planning, environmental consultancy (built and natural environment), agriculture, not for profit, corporate strategies, health assessment and planning, and even into law and decision making (Mason, 2017). Higher education institutions in developing countries such as Nigeria, needs to provide the sustainability foundation for this new reality in order for students to be better prepared for entry into the labour market and generally, contributing to a more sustainable society.

Findings of the study on how incorporating sustainability thinking in to the said curriculum will help achieve environmental protection saw respondents dwelling on waste recycling and renewable energy techniques as possible skills the students will benefit from after passing through a sustainability-based curriculum; and developing strategies for protecting the environment from harmful events such as resource depletion, increased in greenhouse gases, spread of diseases, climate change, water scarcity and loss of natural habitats and biodiversity. These are in agreement with previous literature, such as Majumdar (2009) who opined that achieving environmental protection involves the responsible use of raw materials; energy, water etc, and awareness of the impacts of production processes and environmental auditing system. This is also consistent with the work of Morelli (2013) who viewed environmental sustainability as a condition of balance, resilience, and interconnectedness that allows human society to satisfy its needs while neither exceeding the capacity of its supporting ecosystems to continue to regenerate the services necessary to meet those needs nor by our actions diminishing biological diversity.

When the same question was linked to achieving economic prosperity, respondents commented on producing strong future labour force which will enhance the country's GDP; addressing present widespread job losses, insecurity, and financial risk to governments and public programs; and having a positive thinking towards a system of production that satisfies present consumption levels without compromising future needs. These findings are similar to the assertion of Basiago (1998) who stated that economic prosperity is synonymous to economic sustainability, which implies thinking towards a system of production that satisfies present consumption levels without compromising future needs. Changes towards economic sustainability in Africa sub-Sahara including Nigeria should be corroborated by human resource development that results in important impact on knowledge, skills and attitudes/values. TVET can be a factor to green economic restructuring in the region via building efficient methods regarding establishment of green skills (technical skills, knowledge, values and attitudes) essential for workforce for the transition to an economy with abridged negative impact on the ecosystem.

Incorporating sustainability thinking to achieve social wellbeing were responded and revealed the following: providing solutions to problems like war, endemic poverty, widespread injustice, and low education rates; having an intelligent understanding about social justice and gender equality, democracy, human rights and ethics, work environment issues, accessibility issues and issues related to education; and job security which is vital in preventing a lot of social vices like insurgency, arm robbery, rampant kidnapping, thuggery, and prostitution. The works of Pappas (2012), showed similar results where he refers to social sustainability as the ongoing human and 
institutional balance and prosperity that characterize a healthy social unit, and includes justice, equity, and fairness, the role of individuals, relationships among social groups, the family, collective behavior, social class, race and ethnicity, medicine, education, and the role of institutions in society. Choi and $\mathrm{Ng} \mathrm{(2011)} \mathrm{stated} \mathrm{that} \mathrm{the}$ social dimension of sustainability is concerned with the well being of people and communities as a noneconomic form of wealth.

The findings of the question when linked to achieving technical sustainability reveals that graduates will have a complex understanding of a wide variety of mechanical and technical factors that constitute the design and manufacture of products, processes and systems; and promoting manufacturing processes and industrial practices that are less invasive or destructive to environmental, social or economic contexts and yield ideally, neutral or positive effects on these contexts. The findings are not coming as a surprise because Rosen (2012) in his work identified and examined the key factors that need to be addressed to achieve technical sustainability. They include: sustainable resources, sustainable processes, increased efficiency, reduced environmental impact and fulfillment of other aspects of sustainability. Technical sustainability is, in many ways, more related to green engineering as it focuses on design that requires fewer natural resources, produces less (or no) waste, and reduces, reuses, or recycles waste products.

On a general note, in the light of the findings of the study and their implications, a framework for the need to incorporate sustainable thinking into HND electrical/electronic engineering programmes in the polytechnics are developed as depicted below:

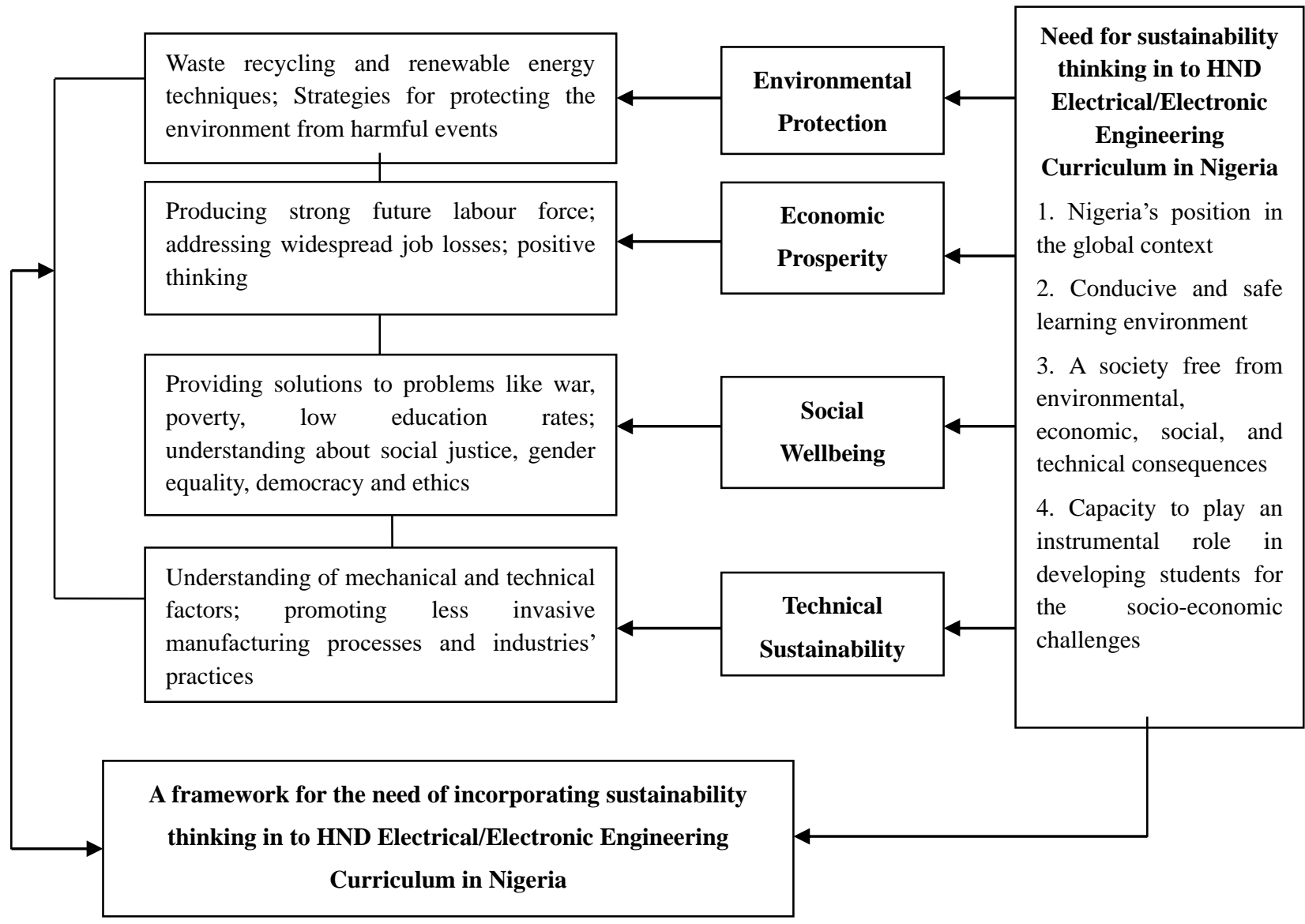

Figure 2. A framework for the Need of Incorporating sustainability thinking in to HND Electrical/Electronic Engineering Curriculum in Nigeria

\subsection{Conclusion}

This study has uncovered the stark truth about the need for incorporating sustainability thinking in to electrical/electronic engineering curriculum at higher national diploma level in Nigeria. The study has also revealed how incorporating sustainability thinking will facilitate environmental protection, economic prosperity, 
social wellbeing and technical sustainability. In respect of the findings and discussion of the study, the following conclusion was reached: That there is need for constant efforts to reorient TVE programmes to sustainability in Nigeria. HND Electrical/Electronic Engineering programmes in the polytechnics are required to incorporate sustainability thinking in to their curriculum to acquaint students with the educational process that deals with the human interrelationships with the environment, economy, social and technical aspects of life.

\subsection{Recommendations}

The following recommendations were made in the light of the findings of this study:

- An empirical study to develop a conceptual model for incorporating sustainable thinking into higher national diploma electrical/electronic engineering curriculum in Nigeria should be carried out.

- $\quad$ Electrical/Electronic engineering departments in the Nigerian polytechnics should embed programmes based on the principles and practices of sustainability within their operations.

- The National Board for Technical Education (NBTE) should provide a level playing ground for the establishment and advancement of sustainability education in the polytechnics.

\section{References}

Aderonmu, P. (2012). A Framework for Sustainable Education in Nigeria: Strategies of Re-Integrating Vocational Skills into Educational Curriculum. A Framework for Sustainable Education in Nigeria: Strategies of Re-integrating Vocational Skills into Educational Curriculum, 1-24.

Akinbile, C. O., \& Yusoff, M. S. (2011). Environmental impact of leachate pollution on groundwater supplies in Akure, Nigeria. International Journal of Environmental Science and Development, $2(1), 81$. https://doi.org/10.7763/IJESD.2011.V2.101

Akinsanya, O., \& Omotayo, K. (2013). Falling standard of engineering education in Nigeria-causes and suggestions. Intl. J Advan. in Res \& Tech, 2(10), 93-103.

Basiago, A. D. (1998). Economic, social, and environmental sustainability in development theory and urban planning practice. The Environmentalist, 19(2), 145-161. https://doi.org/10.1023/A:1006697118620

Blewitt, J. (2014). Understanding sustainable development. Routledge. https://doi.org/10.4324/9781315886459

Bubou, G. M., Offor, I. T., \& Gumus, S. (2015). An argument for the practice of evidence-based teaching in engineering education for developing countries with focus on Nigerian universities. QScience Proceedings, 26. https://doi.org/10.5339/qproc.2015.wcee2014.26

Butler, B. P. (2009). Ecological Balance: The Greater Goal of the Environmental Manager. (Graduate Thesis). Rochester Institute of Technology, Rochester, NY, USA.

Calhoun, J. G., Dollett, L., Sinioris, M. E., Wainio, J. A., Butler, P. W., Griffith, J. R., \& Warden, G. L. (2008). Development of an interprofessional competency model for healthcare leadership. Journal of Healthcare Management / American College of Healthcare Executives, 53(6), 375-389. https://doi.org/10.1097/00115514-200811000-00006

Choi, S., \& Ng, A. (2011). Environmental and economic dimensions of sustainability and price effects on consumer responses. Journal of business ethics, 104(2), 269-282. https://doi.org/10.1007/s10551-011-0908-8

Dainty, A. M. J., Cheng, M-I., \& Moore, D. R. (2010). A competency-based performance model for construction project managers. Construction Management and Economic, 22(8), 877-886. https://doi.org/10.1080/0144619042000202726

Dan'Azumi, S., \& Bichi, M. (2010). Industrial Pollution and Heavy Metals Profile of Challawa River in Kano, Nigeria. Journal of Applied Sciences in Environmental Sanitation, 5(1).

Gu, C. C., Gomes, T., \& Brizuela, V. S. (2011). Technical and vocational education and training in support of strategic sustainable development. Unpublished M. ENGR. Thesis, School of Engineering, Blekinge Institute of Technology, Karlskrona, Sweden

Hidalgo, L. A., \& Arjona Fuentes, J. M. (2013). The development of basic competencies for sustainability in higher education: An educational model.

Huntzinger, D. N., Hutchins, M. J., Gierke, J. S., \& Sutherland, J. W. (2007). Enabling sustainable thinking in undergraduate engineering education. International Journal of Engineering Education, 23(2), 218. 
Majumdar, S. (2009). Major challenges in integrating sustainable development in TVET. CPSC, Manila.

Mason, M. (2017). What is sustainability and why is it important? Retrieved September 6, 2017, from http://www.environmentalscience.org/

Morelli, J. (2013). Environmental sustainability: A definition for environmental professionals. Journal of environmental sustainability, $1(1)$, 2. https://doi.org/10.14448/jes.01.0002

Mukhtar, N. (2014). Occupational Skills Required by Electrical Engineering Graduates of Universities for Effective Performance in Industries of Kano and Kaduna States, Nigeria. Unpublished M.TECH Thesis. Department of Industrial and Technology Education, Federal University of Technology, Minna, Niger state, Nigeria.

Nagel, R. L., Pappas, E. C., \& Pierrakos, O. (2011). On a vision to educating students in sustainability and design-The James Madison University School of Engineering approach. Sustainability, 4(1), 72-91. https://doi.org/10.3390/su4010072

Olaniyan, D., \& Okemakinde, T. (2008). Human capital theory: Implications for educational development. Pakistan Journal of Social Sciences, 5(5), 479-483.

Pappas, E. (2012). A new systems approach to sustainability: University responsibility for teaching sustainability in contexts. Journal of Sustainability Education, 3(1), 3-18. https://doi.org/10.1016/j.jclepro.2012.09.039

Pappas, E., Pierrakos, O., \& Nagel, R. (2013). Using Bloom's Taxonomy to teach sustainability in multiple contexts. Journal of Cleaner Production, 48, 54-64.

Pavlova, M. (2014). TVET as an important factor in country's economic development. SpringerPlus, 3(1), K3. https://doi.org/10.1186/2193-1801-3-S1-K3

Phiri, M.L (2010). A survey of experiences and practices in current use for integrating education for sustainable development in TVET in Botswana. In L. E. Mujangana (Ed.), Integrating sustainable development in Technical and Vocational Education and Training: Sx case studies from southern and eastern Africa.

Ployhart, R. E. \& Moliterno, T. P. (2011). Emergence of the human capital resource: A multilevel model. Academy of Management Review, 36(1), 127-150. https://doi.org/10.5465/amr.2009.0318

Rosen, M. A. (2012). Engineering sustainability: A technical approach to sustainability. Sustainability, 4(9), 2270-2292. https://doi.org/10.3390/su4092270

Rowe, D. (Undated). Education and action for a sustainable future: Opportunities and Resources for you. Oakland Community College, www.oakland.cc.edu/EST

Sianipar, C. P. M., Kiyoshi, D., Gatot, Y., \& Adhiutama, A. (2013). Seven Pillars of Survivability: Appropriate Technology with a Human Face. European Journal of Sustainable Development, 2(4), 1-18.

Sikdar, S. (2009). Achieving technical sustainability. Chemical Engineering. Prog., 72(3),180e220.

Tilbury, D. (2011). Higher education for sustainability: A global overview of commitment and progress. Higher education in the world, 4, 18-28.

Ukpai, U. I. (2012). Effective Management of Nigerian Polytechnics Challenges and Remedies. Paper Presented at the $3^{\text {rd }}$ Annual National Conference of School of General Studies on the Theme: Trends in Nigerian Tertiary education at Abia State Polytechnic, Aba, November $13^{\text {th }}-16^{\text {th }}, 2012$

UNEP. (2005). Strategy for Environmental Education and Training: A Strategy and Action Planning for the Decade 2005-2014.

UNESCO. (2008). Education for All by 2015, Will We Make It? EFA Global Monitoring Report. Oxford: Oxford University Press, Downloaded from efareport.unesco.org

UNESCO. (2016). Education for People and Planet: Creating Sustainable Futures for All. Paper Commissioned for the Global Education Monitoring Report; 2016.

UNESCO. (2005). Report by the Director-General on the United Nations Decade for Education for Sustainable Development. International implementation Scheme and UNESCO's Contribution to the Implementation of the Decade (172 EX/11). Paris: UNESCO. Retrieved from http://unesdoc.unesco.org/images/0014/001403/140372e.pdf

UNESCO. (2009). Review of contexts and structures for education for sustainable development.

UNESCO. (2011). Financing education in sub-Sahara Africa: Meeting the challenges of expansion, equity and 
quality. UNESCO.

WCED. (1987). Our Common Future. World Commission on Environmental and Development. Oxford University Press, Oxford.

Wiek, A., Withycombe, L., Redman, C., \& Mills, S. B. (2011). Moving forward on competence in sustainability research and problem solving. Environment, 53(2), 3-13. https://doi.org/10.1080/00139157.2011.554496

\section{Copyrights}

Copyright for this article is retained by the author(s), with first publication rights granted to the journal.

This is an open-access article distributed under the terms and conditions of the Creative Commons Attribution license (http://creativecommons.org/licenses/by/4.0/). 